\title{
Latex allergy in association with tissue expansion
}

\author{
Ronald M Zuker MD FRCSC FACS, Marius Sapijaszko \\ Division of Plastic Surgery, The Hospital for Sick Children, Toronto, Ontario
}

RM Zucker, M Sapijaszko. Latex allergy in association with tissue expansion. Can J Plast Surg 1995;3(3):163-165. This case report outlines the sequence of events in an intraoperative anaphylactic reaction as the pockets for tissue expanders were bing developed. Previous expansion had been carried out uneventfully suggesting previous sensitization. Subsequent testing revealed significant latex allergy. Latex avoidance during repeated tissue expansion is recommended.

Key Words: Giant hairy nevi, Latex, Tissue expansion

\section{Allergie au latex en association avec une expansion tissulaire}

RÉSUMÉ : Ce rapport de cas souligne la séquence d'événements ayant trait à une réaction anaphylactique peropératoire au moment où les poches destinées à une expansion tissulaire étaient en cours d'élaboration. Une expansion précédente avait été effectuée sans problème, ce qui suggère une sensibilisation préalable. L'épreuve subséquente a révélé une importante allergie au latex. Il est recommandé d'éviter le latex lors d'expansions tissulaires répétées.

Anaphylactic reactions during surgery are rare events. When they do occur, however, all members of the surgical team must work quickly and in concert to avert a catastrophe. Most cases can be related to drug administration. However, latex products may produce such reactions and these are being reported with increased frequency (1-11). In this case study, we report on a young girl who suffered an anaphylactic reaction at the time of tissue expander insertion. We will discuss her management as well as the factors that contributed to the problem and how such factors may be controlled in the future.

\section{CASE REPORT}

On April 19, 1993 a nine-year-old girl was admitted for insertion of tissue expanders to the back and shoulders. This was designed to expand normal skin adjacent to her giant hairy nevus and facilitate reconstruction following excision. She had previously undergone 11 surgeries, four in Hong Kong (Figure 1) and seven in Toronto (Figure 2) for this condition (Table 1). She had no known allergies and was on no medication. Her preoperative blood pressure was $110 / 60 \mathrm{mmHg}$ and her hemoglobin was $136 \mathrm{~g} / \mathrm{L}$. All procedures noted in Table 1 were well tolerated with no systemic 
complications. The histopathology of the excised tissue had consistently demonstrated a congenital intradermal hairy nevus with no evidence of malignancy.

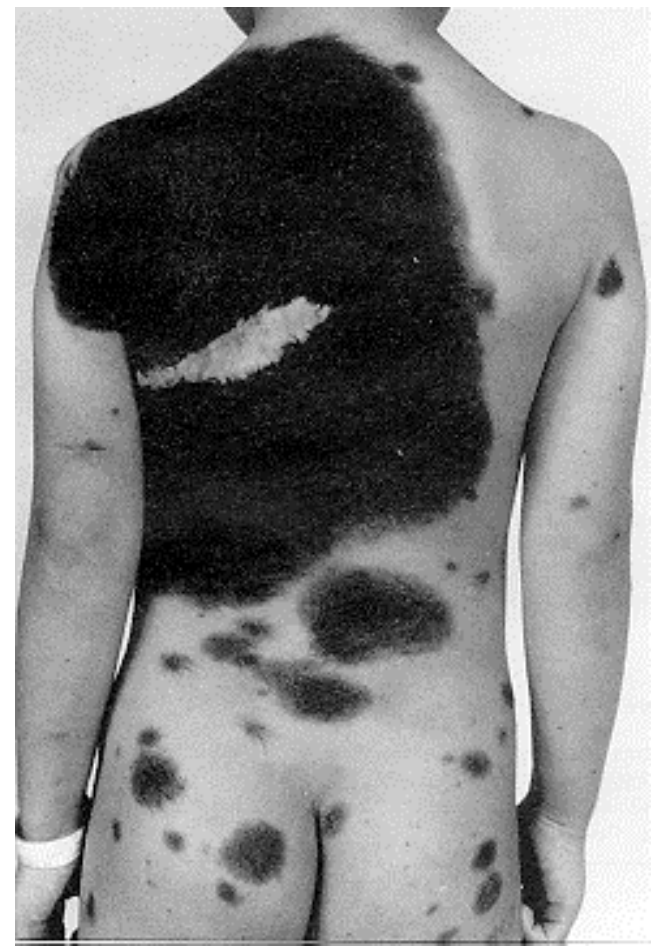

Figure 1) Appearance of patient upon arrival in Canada

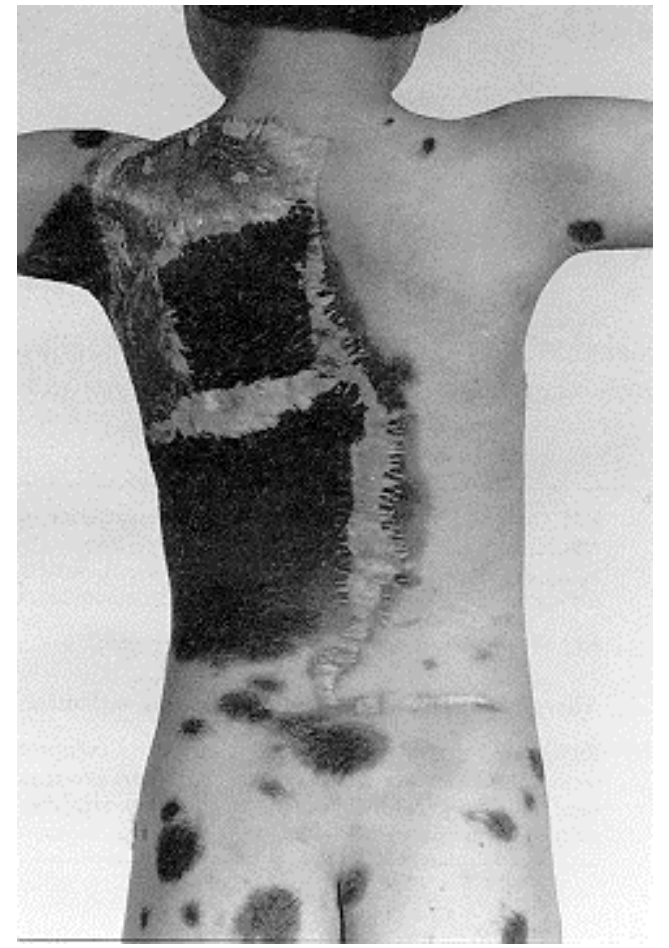

Figure 2) Appearance of patient part way through reconstructive process (January 1991)

TABLE 1: Surgical history of patient

\begin{tabular}{|c|c|}
\hline Prior to 1990 & $\begin{array}{l}\text { Four surgeries in Hong Kong with excision of nevi and primary closure on } \\
\text { excision of nevi with meshed split thickness skin grafts }\end{array}$ \\
\hline $\begin{array}{l}13 \text { February } \\
1990\end{array}$ & $\begin{array}{l}\text { Excision of back nevus with skin grafting and insertion of three tissue } \\
\text { expanders }\end{array}$ \\
\hline \begin{tabular}{|l|l}
27 April \\
1990
\end{tabular} & Excision of large hairy nevus and tissue expanded flap reconstruction \\
\hline $\begin{array}{l}11 \text { January } \\
1991\end{array}$ & Insertion of three tissue expanders to the back. \\
\hline $\begin{array}{l}25 \text { January } \\
1991\end{array}$ & Removal of infected tissue expander from the upper back \\
\hline 6 May 1991 & $\begin{array}{l}\text { Removal of tissue expanders from the back, partial excision of nevus from } \\
\text { the back, rotational and advancement flaps }\end{array}$ \\
\hline $\begin{array}{l}24 \text { April } \\
1992\end{array}$ & Insertion of three tissue expanders to the back \\
\hline 24 July 1992 & Removal of tissue expanders with rotational and advancement flaps \\
\hline
\end{tabular}


General anaesthesia was induced, she was placed in the prone position and cefazolin $500 \mathrm{mg}$ given intravenously (iv). The incisions were outlined and infiltrated with $24.5 \mathrm{~mL}$ of $0.25 \%$ bupivacaine with 1:200,000 adrenaline. Sixty-six minutes after the time of induction, her oxygen saturation dropped to $93 \%$ and her airway pressures rose. With chest auscultation, widespread and severe wheezing could be heard. Her blood pressure dropped to $68 \mathrm{mmHg}$ and a generalized maculopapular rash was noted, especially in the operative field (Figure 3). At that time, the large pockets of undermined skin and subcutaneous fat had been created but the tissue expanders themselves had not been removed from their sealed containers. The child was immediately resuscitated with a bolus of lactated Ringers, adrenaline and hydrocortisone. After she was stabilized, the expanders were inserted, the wounds were closed and she was transferred to the intensive care unit. She required ventilatory support and vasopressors including dopamine for just over $48 \mathrm{~h}$ and then was gradually weaned from these and transferred to the hospital ward on the fifth postoperative day. Once on the ward she recovered quickly and, after some preliminary investigations as to the cause of the reaction, was discharged home.

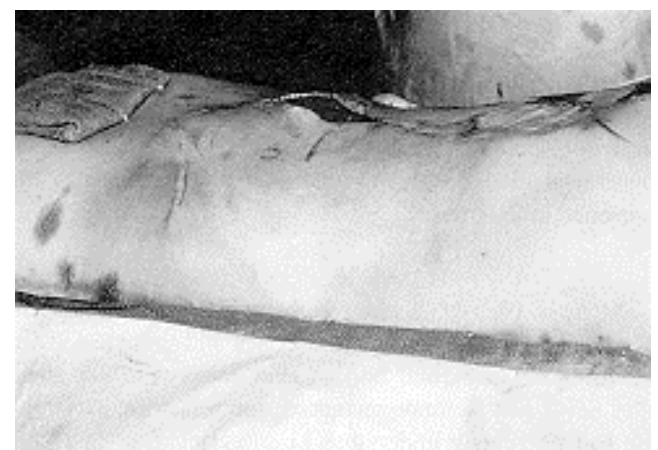

Figure 3) Intraoperative maculopapular rash in operative site

Two weeks later the weekly injection of the expanders began. Assuming latex to be a possible cause, all injections were carried out with a latex-free technique, ie, latexfree gloves and immediate injection of saline from the bag to the patient with no delay. Thus, saline did not stay in the syringe (the stopper has latex) for any length of time. Allergy testing was carried out which confirmed latex allergy, thus absolving any of the anaesthetic agents (Table 2). Expander inflation continued uneventfully and on July 27, 1993, surgery for removal of the expander, excision of the residual nevus and reconstruction with the expanded skin was performed. A latex free environment was used. The child was premedicated with hydrocortisone $5 \mathrm{mg} / \mathrm{kg}$ iv, q6h x 3 , diphenydramine $1 \mathrm{mg} / \mathrm{kg}$ iv q6h x 3 and ranitidine $1 \mathrm{mg} / \mathrm{kg}$ iv q12h x 2 . There were no intraoperative problems. She remained on bed rest and careful observation postoperatively and was discharged home on the sixth day (Figure 4). 
TABLE 2: Results of allergy testing

\begin{tabular}{|l|l|l|l|l||}
\hline Substance & Concentration & Result & Concentration & Result \\
\hline Histamine & - & Weal of $5 \times 10 \mathrm{~mm}$ & - & - \\
\hline Saline & - & Negative & - & - \\
\hline Latex & - & Weal of $5 \times 10 \mathrm{~mm}$ & - & - \\
\hline RAST & - & Positive & - & - \\
\hline Atracuronium & $1: 100$ & Negative & $1: 1000$ & Negative \\
\hline Morphine & $1: 10,000$ & Negative & $1: 1000,000$ & Negative \\
\hline Pancuronium & $1: 100$ & Negative & $1: 1000$ & Negative \\
\hline Thiopentol & $1: 10$ & Negative & $1: 100$ & Negative \\
\hline
\end{tabular}

\section{RAST Radioallergosorbent test}

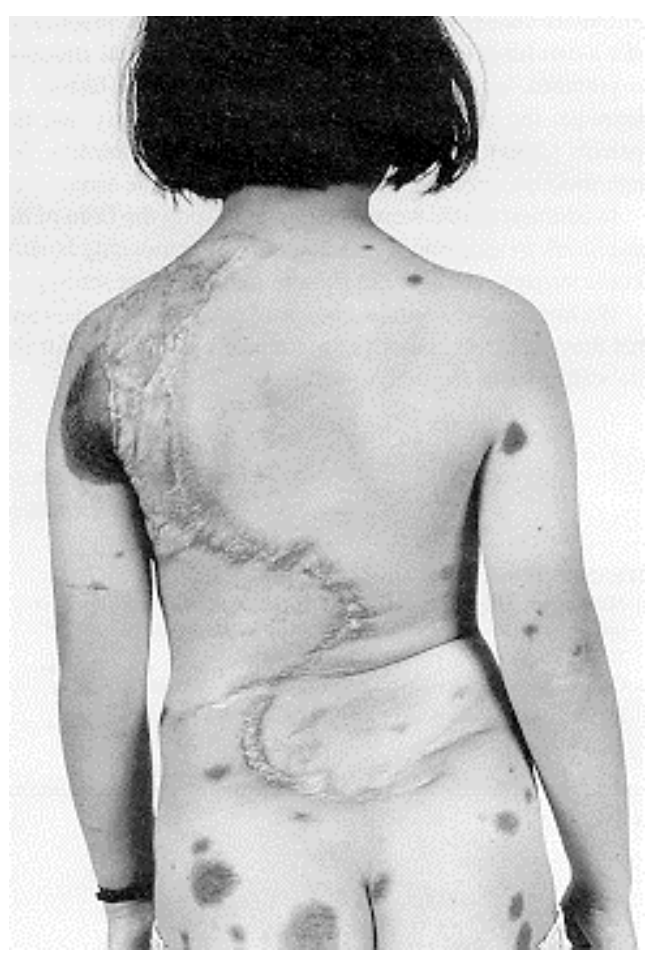

Figure 4) Final result after expander removal and reconstruction

\section{DISCUSSION}

Latex or natural rubber is a product obtained from the sap of the rubber tree, Hevea brasiliensis. After purification, processing and the addition of certain additives, a synthetic rubber is formed that is used in the production of surgical gloves, condoms, urinary catheters, adhesives, etc. Allergy to these products may take the form of contact dermatitis (common in surgeons and anaesthetists, patients with spina bifida or others requiring frequent catheterization) or IgE mediated anaphylaxis. Our patient had no previous history of atopy and no known condition which would predispose her to latex allergy. However, she did have numerous previous surgeries. In fact, she had had 11 
operations with three previous tissue expander procedures. At these times, large pockets were created beneath normal skin. Thus, tremendous areas were opened up and in contact with latex containing surgical gloves. This repeated heavy exposure was possibly instrumental in the production of her allergy. It went unrecognized until the anaphylactic reaction occurred.

Latex antigens are absorbed through mucosal membranes and possibly tissue expander capsules. They bind to human immunoglobulin (Ig)E and set the stage for the IgE-mediated hypersensitivity response seen in latex allergy. Patients at risk should be screened by simple skin tests, specific IgE antibodies or, when indicated, by specific immunological techniques (eg, radioallergosorbent test -- RAST). Precautions to latex allergy would seem wise in patients requiring multiple tissue expander procedures, such as in giant congenital hairy nevi.

Appropriate precautions should at least begin with the use of latex free surgical gloves. This has now become standard practice at our institution.

\section{REFERENCES}

1. Arellano R, Bradley J, Sussman G. Prevalence of latex sensitization among hospital physicians occupationally exposed to latex gloves. Anesthesiology 1992;77:905-8.

2. Barakat RR, Sararian K, Shepherd G, Weinberger M, Hoskins WJ. Allergy to latex surgical gloves: An unfamiliar cause of intraoperative anaphylaxis. Gynecologic Oncology 1992;46:381-3.

3. D'Astous J, Drouin MA, Rhine E. Intraoperative anaphylaxis secondary to allergy to latex in children who have spina bifida. J Bone Joint Surg 1992;74:1084-6.

4. Gerber AC, Jorg W, Zbinden S, Seger A, Dangel PH. Severe intraoperative anaphylaxis to surgical gloves: Latex allergy, an unfamiliar condition. Anesthesiology 1989;71:800-2.

5. Holzman RS. Latex allergy: An emerging operating room problem. Anesth Analg 1993;76:635-41.

6. Leger RR, Meeropol E. Children at risk: Latex allergy and spina bifida. J Pediatr Nursing 1992;7:371-6.

7. Leynadier F, Pecquet C, Dry J. Anaphylaxis to latex during surgery. Anaesthesia 1989;44:547-50.

8. McKinstry LJ, Fenton WJ, Barrett P. Can J Anaesth 1992;39:6:587-9.

9. Meehan PL, Galina MP, Daftari T. Intraoperative anaphylaxis due to allergy to latex. J Bone Joint Surg 1992;74:7:1087-9.

10. Slater JE, Mostello LA, Shaer C, Honsinger RW. Type I hypersensitivity to rubber. Ann Allergy 1990;65:411-4.

11. Swartz J, Braude BM, Gilmour RF, Shandling B, Gold M. Intraoperative anaphylaxis to latex. Can J Anaesth 1990;37:5:589-92. 